\title{
Edebiyat Tarihçiliğinin Ana Sorunsalı: Öncü Kim, Ölçüt Ne?
}

\section{Muharrem DAYANÇ1}

\author{
$\ddot{O} \mathbf{z}$
}

\begin{abstract}
Edebiyat tarihi belli kabullerle zemini oluşturulan bir sosyal bilimler alanı olarak dikkat çeker. Bu kabullerin ortaya çıkmasını daha çok devrin ideolojisi, edebi moda ve akımlar, bakış açısı, sosyal koşullar, bireysel tercihler gibi unsurlar belirler. Bu unsurlardan baskın olan birinin veya birkaçının bir araya gelmesi bir yazarı, eseri, akımı, dönemi öne çıkarmaya (yüceltme) neden olabilir. Yine bu unsurlardan birinin veya birkaçının değer kaybetmesi/değişmesi bir yazarı, eseri, akımı, dönemi gündemin uzağına (değersizleştirme) itebilir. Bu olumlu veya olumsuz gelgitleri, yer değiştirmeleri her zaman sosyal bilimlerin nesnel ölçüleriyle açıklamak çok da mümkün olmayabilir. Bütün bu problemlerin ortaya çıkışlarının arkasındaki temel neden sosyal bilimlerdeki “ölçü” sorunudur. Bu bahsin Türk edebiyatındaki en çarpıcı örneklerinden biri Yunus Emre'dir. Yunus Emre'nin alt yüz yıllık bir zaman diliminde aydın kesimin hemen hemen hiç ilgisini çekmemesi ile yirminci yüzyılın başında birden bire değer kazanması nesnel ve estetik ölçülerle izahı çok da kolay olan bir durum gibi görünmez. Öncü ve ölçüt bahsinde bu ve buna benzer durumlar birçok şahıs, eser, akım ve dönem için de geçerlidir, denilebilir. Bu bildiride bugüne kadar öncü olarak kabul edilen şahıs, eser, akım ve dönemlerin bu imtiyazı elde etme veya kaybetmelerinde kabul gören ölçütler Berna Moran’ın "beğeni yargıları" ve "değer yargıları" kavramlaştırmaları bağlamında eleştirel bir gözle ve somut örneklerden hareketle ele alınıp değerlendirilecektir.
\end{abstract}

Anahtar kelimeler: Edebiyat tarihi, edebiyatta öncü ve ölçüt, beğeni ve değer yargıları.

\section{The Main Problematic of Literature Historiography: Who is the Pioneer, What is the Criterion?}

\begin{abstract}
Literature history attracts attention as a social sciences area that is formed by certain acceptances. The emergence of these acceptances are mostly determined by elements such as ideology of period, literary fashions and trends, perspective, social conditions, individual preferences. The combination of one or a few of these elements may cause to foregrounding (dignification) an author, a work, a trend and an era. And also, the decrease in value/change of one or a few of these elements can drive an author, a work, a trend and an era away (trivializing) from the order. It can not be always possible to explain these positive or negative tides, relocations in the way of the objective criterions of social sciences. The main reason behind the emergence of all these problems is the "criterion" issue. One of the most striking examples of this subject in Turkish literature is Yunus Emre. The lack of interest of intellectual segment towards Yunus Emre, in a period of six-hundred years and a sudden appreciation of him at the beginning of the twentieth century do not seem to be a fact to be explained with objective and aesthetical criterions. In the case of the pioneer and the criterion, it can be said that these and similar situations are also effective for many people, works, trends and periods. In this article, the criterions that are accepted in obtaining or loosing a privilege of people, works, trends and eras which are respected as a pioneer until today, will be reviewed in the context of Berna Moran's conceptions
\end{abstract}

Prof. Dr., İstanbul Medeniyet Üniversitesi, Edebiyat Fakültesi, Türk Dili ve Edebiyatı Bölümü, mdayancm@gmail.com [Makale kayıt tarihi: 6.6.2018-kabul tarihi: 15.8.2018] 
of "appreciation judgments" and "worth judgments" by a critical eye and with reference to concrete examples.

Key words: Literature history, the pioneer and the criterion of literature, appreciation and worth judgments.

\section{Giriş}

Edebiyat tarihinin (ve dolayısıyla teorisinin) özellikle yirminci yüzylldan sonra ortaya koyduğu çalışmaların hemen hepsinin ulaşmak istediği nihai amaç/hedef edebî eserlerin iç ve dış unsurlarından hareketle edebiyatta bir ölçü oluşturma/geliştirme çabasıdır, denilebilir. Edebiyat kuramları nasıl, eser, yazar, okuyucu, toplum vb. unsurlardan hareketle edebî eserlere farklı açllardan yaklaşma imkânlarına sahiplerse, edebiyatta ölçü/ölçüt bahsi de konuya ilgi duyanların bakış açılarına ve tercihlerine göre değişiklik gösterebilir. Konu ölçü/ölçüt bahsi olunca elbette böyle olmaması beklenir, daha evrensele açı, sosyal bilimlerin hemen her alanına/eserine uygulanabilen normların ortaya çıkması ve geliştirilmesi umulur, ama günümüzün pratikleri durumun pek de böyle olmadığını ortaya koyuyor.

Ölçünün/ölçütün çerçevesi dar anlamda “yargı kalıpları" veya "şablon/klişe oluşturmak” gibi sözcüklerle ifade edilebileceği gibi geniş anlamda bir dönemi, kişiyi, eseri, olguyu estetik bağlamda değerlendirebilmek için temel ilkeleri belirlemek şeklinde düşünülebilir. "Yargı kalıpları", "şablon-klişe oluşturmak", "temel estetik ilkeleri belirlemek" uzun bir zamana, kültürel ve estetik birikime, sözlü edebiyat döneminden günümüze kadar çok sayıda örnekleme, bunlarla birlikte nesnel bir gözlem ve tasnif gücüne ihtiyaç duyar. Bu unsurlar bir araya gelmez veya getirilemezse Yunus Emre gibi kurucu, yol açıcı dehaların künhüne vakıf olmak için yüzyıllar kâfi gelmeyebilir. Bu fark edemeyişler, dil ve kültürün zamanla başka mecralara savrulması sonucunu doğurur ki bunun olumsuz etkilerini bertaraf etmek kolay olmayabilir.

$\mathrm{Bu}$ bildirinin teorik altyapısı, Berna Moran'ın geliştirdiği, “dayanakları gösterilebilirse de bu dayanakların yargıyı verenin öznel beğenisini açıkladığı ve dayanakları sunanın yargısını başkalarının beğenmesini beklemediği” beğeni yargısı ile "dayanakları yargı sahibinin beğenisiyle ilgisi olabileceği gibi sadece bu kişisel beğeniden doğmayan, gösterilen dayanaklarla eseri iyi veya kötü kılıcı nitelikleriyle başkalarının da yargıyı paylaşmasını beklediği” değer yargısı kavramları üzerine oturtulacaktır.2 Hemen fark edileceği üzere bu yargıların ilkinde öznel, ikincisinde nesnel yaklaşım öne çıkar.

\section{Örneklerden yargılara veya ölçü(t)lere yolculuk}

Bu bölümde, adında "ölçü/ölçüt" bulunan üç metinden hareketle edebiyat tarihi ve teorisinin en temel sorun alanlarından biri olan "edebiyatta ölçü/ölçüt" konusu eleştirel bir gözle ortaya konulmaya çalışlacaktır. ${ }^{3}$

\footnotetext{
Berna Moran, "Estetik Yargılar”, Edebiyat Kuramları ve Eleştiri, Cem Yayınevi, İstanbul 1994, s. 295.

Türk edebiyatında ölçü/ölçüt bahsini başlı̆̆ına taşıyan birçok yazı bulunmaktadır, bunların yukarıda ele alınanlar dışında ilk akla gelenleri şunlardır: Abdullah Ş̧engül, "Değişimin Öncüleri: Model Şahıslar ve Türk Edebiyatına Yansımaları", Erdem Dergisi, Sayı: 47, Ankara 2006, AKM Yayınları, s. 129-154.; Fikret Uslucan, "Öncü Roman Kavramı Açısından Bereketli Topraklar Üzerinde”, Hece -Türk Romanı Özel Sayısı-, Sayı: 65-66-67, Mayıs-Haziran-Temmuz 2002, s. 622641.; Mahfuz Zariç, “Abdulhak Şinasi Hisar'ın Öncü Kişiliğii, Sanatı ve Eseri Üzerine Notlar”, Hece, Sayı: 214, Ekim 2014, s. 139-146.; Mahir Ünlü, "Eleştirinin Ana Çizgileri, -Eleştiride Ölçütler, Öğeler, Yöntemler-”, Türkçede Yazınsal Eleştiri, İnkılap Kitabevi, İstanbul 1997, s. 48-86.; Yılmaz Taşçıŏlu, "Modern Türk Şiirinin Oluşumunda Yahya Kemal'in Yeri”, İstanbul Yahya Kemal Enstitüsü Mecmuası V, İstanbul Yahya Kemal Enstitüsü Neşriyat1, İstanbul 2008, s. 749-753.
} 
İlk olarak, Cumhuriyet devrinin önde gelen eleştirmenlerinden biri olan Fethi Naci'nin Türk Romanında Ölçüt Sorunu adlı eserinden iki yazısı üzerinde durulacaktır. ${ }^{4}$ 1980-1986 yılları arasında yazılmış toplam yüz altı denemeden oluşan bu kitapta ölçü/ölçüt bahsiyle alâkalı iki metin vardır. F. Naci, “Türkiyede Roman Var mı?” başlıklı ilk yazısına Türk romanı ile Avrupa romanını karşılaştırarak başlar. Daha sonra Türk romanının gecikme nedenlerini maddeler halinde sıralar ve Fakirt Baykurt, Orhan Kemal, Reşat Nuri, Yakup Kadri ve Halide Edip'e değişik açılardan eleştiriler getirir. Yaptığı bu kısa değerlendirme ve eleştirilerden sonra F. Naci, Nathalie Sarraute'un Kuşku Çağ $\imath^{5}$ adlı eserinden hareketle, ${ }^{6}$ roman bahsiyle ilgili şöyle bir ölçüt geliştirir:

"Bir romanın büyüklüğü nasıl anlaşılır? Belki birtakım nesnel ölçütleri vardır bunun, ama bir de doğruluğu 'bittecrübe' denenmiş bir ölçüt vardır: O romanı yeniden okumak isteği. Sorarım: Hangi Türk romanını okuduktan sonra bir kez daha okumak isteğini duydunuz?”7

F. Naci, bir romanın büyüklüğünü gösteren temel ölçütlerden birini bittecrübe -'ben tecrübe ettim' anlamında- "bir romanı okuduktan sonra yeniden okumak isteği" olarak belirliyor. Geliştirdiği ölçütün hemen altında, yeniden okuma isteğini duyduğu tek Türk romancısının Ahmet Hamdi Tanpınar olduğunu da belirterek bahsi kendince somutlaştırıyor.

Kitapla aynı adı taşıyan bir sonraki yazısında F. Naci yukarıda kısaca özetlediğimiz ilk yazısına yöneltilen eleştirileri tek tek sıralar. Bu eleştiriler içinde yazara göre saygıyı hak edenler de vardır etmeyenler de. Büyük bölümünü “yeniden okumak istediği tek Türk romancısı” Tanpınar'ın 1936'da Kültür Haftası'nda yayınlanan "Bizde Roman"8 adlı makalesinden yaptığı alıntılarla doldurduğu yazısının sonuna doğru F. Naci yeni bir ölçüt daha geliştirir:

“Öyle sanıyorum, Türk romanının en büyük sorunu, ölçüt sorunu. Türk romanını neye göre değerlendireceğiz? Bugün Batılı romancıların önlerinde kendi ülkelerinin geçmişteki dev romancıları var; ölçüt, onlar. Bizde böyle bir şey yok. O zaman Türk romanlarını roman gelişimimiz içinde değerlendirmek, yeni ortaya çıan bir romancıyı bir Halit Ziya ile, bir Tanpınar'la, bir Reşat Nuri ile, bir Yaşar Kemal’le karşılaştırmak bir anlam taşımıyor. Türk romanları için ayrı ölçüt, Batı romanları için ayrı ölçüt kullanamayız artık; ikisi için de ölçüt, tek ve aynı.”9

F. Naci duygusal bir ölçütten, uluslar üstü bir ölçüte geçer ve Türk romanının Batı romanı karşısındaki yerini sorgular. Bu noktada ölçüt kavramıyla ilgili temel sorunsal, bu kavramın yerel mi yoksa yerel üstü (evrensel) mü olacağı bahsidir ki F. Naci’nin görüşleri daha çok yereli aşan bir bakış açısından yanadır.

Fethi Naci, Türk Romaninda Ölçüt Sorunu Eleştiri Günlüğ̈̈ I (1980-1986), YKY, İstanbul 1986, 319 s.

Nathalie Sarraute, Kuşku Çağ , Çev. Bedia Kösemihal, Adam Yayınları, İstanbul 1985, 93 s.

Fethi Naci, "Öznel Bir Ölçüt”, Gücünü Yitiren Edebiyat Eleștiri Günlüğü II (1986-199o), YKY, İstanbul 2002, s. 85.

Fethi Naci, “Türkiye’de Roman Var mı?”, Türk Romanında Ölçüt Sorunu Eleştiri Günlüğü I (1980-1986), YKY, İstanbul 1986, s. 15. (Berna Moran da yukarıdaki görüşlere yakın sözler söyler: "Bir eserin gelişi güzel kurulmuş olmasını istemeyiz, tutarlı bir şekilde düzenlenmiş olmasını isteriz. Başka bir deyişle birlik her eserde aranan bir meziyettir, yani bir normdur. Bundan başka, bir sanat eserinin, tekrar okumak (görmek, dinlemek) isteğini uyandıracak kadar karmaşı olması beklenir. Belki üçüncü bir norm olarak yoğunluk sürülebilir ileri.” (Berna Moran, "Estetik Yargllar”, Edebiyat Kuramlar ve Eleştiri, Cem Yayınevi, İstanbul 1994, s. 289).

8 Tanpınar 1936'da Kültür Haftası’nda aynı balıkla peş peşe iki yazı yazmıştır. Bilgi için bkz: (Edebiyat Üzerine Makaleler, Dergâh Yayınları, İstanbul 2000, s. 47-54).

Fethi Naci, "Türk Romanında Ölçüt Sorunu”, Türk Romanında Ölçüt Sorunu Eleştiri Günlüğü I (1980-1986), YKY, İstanbul 1986, s. 21-22. 
İkinci olarak bir şairin, Edip Cansever’in, kitabına da adını veren "Şiiri Şiirle Ölçmek" adlı yazısı üzerinde durulacaktır. ${ }^{10}$ 1961'de Yeditepe'de çıkan bu yazı, yayınlandığı zamanın bir ayrışmasına vurgu yaparak başlar. Bu ayrışmada bir iki sanatçı öne çıkmakta bunların dışındakiler "soyuta kaçmak"la eleştirilmektedir. Bu eleştiriyi yapanlardan biri, sonradan çark etmekle birlikte, Yaşar Kemal'dir. Soyutsomut tartışmasına müdahil olan diğer yazarlar Metin Eloğlu ile Cemal Süreya'dır. Metin Eloğlu, "soyutsomut şiir bahsine bir toplumbilimci” gibi bakar. Cemal Süreya’nın bakışı "daha bir şairce”dir.

Giriş olarak düşünülebilecek bu değerlendirmelerden sonra Cansever, şiir sanatı için, "şiiri yine şiirin terazisinde tartmak" şeklinde özetlenebilecek bir ölçüt geliştirir:

\begin{abstract}
"Bence şiiri değerlendirmek bakımından tutulacak en iyi yol şu olmalıdır: Şiiri şiirle ölçmek... Yani şiire, salt iç tepkilerimize uyarak değil de, tarihin, yaşadığımız çağın, belli bir şiir geleneğinin, okuduğumuz şiir sayısının, edindiğimiz şiir ekininin aracılığıyla bakmak gerekir. Ancak bu yolladır ki, şiirin gerçek yapısını, gerçek düzenini, çağlar boyu değişmeyen yanını kavrayabiliriz; gelgeç yenilikle, bir temele bağlı olan yeniliği kolayca ayırt edebiliriz. Oysa çoğu kimseler, bir şiir okudular $\mathrm{m}$, olanca duygularını, olanca heyecanlarını boşaltıverirler; kendi iç evrenlerinde bir yapı, bir düzen kurmaktan uzak kalırlar. Şiir değil de, buna benzer herhangi bir olayla karşılaşsalar, durumları gene de değişmeyecektir. Yargıları da beğenileri de günlük, hatta anlık etkilenmelerin sonucudur, sağlam değildir."11
\end{abstract}

Fethi Naci'deki "bittecrübe/öyle sanıorum” ibarelerinin yerini Edip Cansever'de "ben” zamirinin anlamca hemen yanı başında duran "bence" kelimesi alır. Cansever, kendince geliştirdiği bu ölçütte “an”lık duygulardan hareketle yapılan öznel değerlendirmelerle arasına mesafe koyar. O, şiire geçmiş, bugün ve geleceğin birikimi, nitelikli şiir okurluğu, bilgisi ve kültürü üzerinden bakmanın daha doğru olacağını düşünür. Okur/araştırmacı bu yolla duygusal ve zamansal tuzaklardan kurtulup "şiirin çağlar boyu değişmeyen yanı”nı kavrayabilir. Günlük/anlık beğenilerin tuzağından kurtulmak ancak böylesine bütüncül bir bakışa ulaşmakla mümkündür.

Üçüncü olarak bir akademisyenin, İnci Enginün'ün, 27-28 Mayıs 2003’te Bilkent Üniversitesi’nde "Hayal Şiir" adıyla düzenlenen Yahya Kemal Sempozyumu'nda sunduğu, 2008'de bildirilerin biraraya toplandığı kitapta yer alan "Yahya Kemal: Edebiyatta Ölçüt” başlıklı yazısı üzerinde durulacaktır. ${ }^{12}$

Yazıda dikkati çeken ana unsur Enginün'ün yazıyı "ben” zamiri ve bakış açısı üzerine inşa etmesidir. Enginün bu bildiride görüşlerini tartışmaz, üstten bir bakışla adeta dikte eder. Yazının daha ilk iki cümlesi bu yargıyı doğrular:

"Yahya Kemal adı ile edebiyat, özellikle şïrdeki ölçüt kavramları neredeyse eş anlamlıdır. Şiirde bir ölçüte ihtiyaç var mıydı sorusunun cevabı bence evettir.”

Yahya Kemal'i “Tanrı Şair”"13 olarak tebcil eden yaklaşımları akla getiren bu cümleler ölçü/ölçüt bahsinin Türk edebiyatındaki farklı bir yönünü ortaya koyması bakımından çarpıcıdır.

\footnotetext{
$10 \quad$ Edip Cansever, "Şiiri Şiirle Ölçmek”, Şïiri Şiirle Ölçmek Şïr Üzerine Yazılar, Söyleşiler, Soruşturmalar, Hazırlayan: Devrim Dirlikyapan, YKY, İstanbul 2012, s. 108-112.

Edip Cansever, "Şiiri Şiirle Ölçmek", Şiiri Şiirle Ölçmek Şïr Üzerine Yazılar, Söyleşiler, Soruşturmalar, Hazırlayan: Devrim Dirlikyapan, YKY, İstanbul 2012, s. 110.

İnci Enginün, "Yahya Kemal: Edebiyatta Ölçüt", Hayal Şïr Yahya Kemal Beyath Şïri Üzerine Makaleler, Türkiye İş Bankası Kültür Yayınları, İstanbul 2008, s. 149-166.

$13 \quad$ M.Şekip Tunç, "Tanrı Şair”, Cumhuriyet, 9 Ekim 1938.
} 
Bu cümlelerden sonra yazı Tanzimat'tan başlayarak Türk şiirinin yenileşme tarihi üzerine yoğunlaşır. Bunun nedeni, Yahya Kemal’in hangi değişimlerden sonra nasıl bir şiir anlayışının içine doğduğunun somut olarak tespit edilmek istenmesi olabilir.

Bahis Yahya Kemal’in Paris'ten döndüğü ylllara (1912) gelince konu da normal olarak “öz şiir”e evrilir. Bu noktada Ahmet Haşim’in de adını anan Enginün yazının devamında, şairin "kendisinden önceki Türk edebiyatıyla/şiiriyle ilgili olarak yaptığı değerlendirmeleri” maddeler halinde sıralar: Yahya Kemal, Namık Kemal'in etkisini kırarak divan edebiyatına hak ettiği değeri vermiştir; vezin ve kafiye bahsinde olduğu gibi gereksiz detaylara inen edebî tartışmalara uzak durmuştur; eleştirdiği yazarların bile (Namık Kemal/Abdülhak Hamit) olumlu taraflarını görmezden gelmemiş bütüncül bir bakışla bu müellifleri yok saymamıştır; güdümlü edebiyata, talimatla şiir yazmaya uzak durmuştur; Millî Mücadele’yi ve Millî Mücadele’nin önderini daima yüceltmiş ve bu tavrıyla öğrencilerine rol model olmuştur.

Bu maddelerin altıncı ve sonuncusu direkt ölçü/ölçüt bahsiyle ilgili olduğu için diğerlerinden bir adım öne çıkar:

"Yahya Kemal çevresini kesinlikle çok etkilemiştir. Buna dair birçok yerde kısa bilgi kırıntılarıyla karşılaşılmaktadır. O, şair olma heveslilerinin önünde bir ölçüttür.”14

Yahya Kemal'i “şair olma heveslilerinin önünde bir ölçüt” olarak değerlendiren Enginün, bu bahse, yer yer eleştirmekle birlikte hocasını kendisine rol model olarak seçen Tanpınar’ı örnek gösterir. Sonrasında ise Mustafa Nihat Özön, Nurullah Ataç ve Ahmet Kutsi Tecer’i Tanpınar'la birlikte Yahya Kemal'in öğrencileri arasında sayar.

Enginün'e göre, Yahya Kemal’i yirminci yüzyıl Türk edebiyatında yol açıcı (öncü) yapan bir diğer unsur "hakkındaki tartışmalar"dır. Zaman zaman şiir sanatına da değinilmekle birlikte bu tartışmalarda bahis bir türlü şiirin estetik yönüne gelmez ve dedikodu boyutunda kalır. Birikimlerini çevresindekilere daha çok sohbet yoluyla, sözlü olarak aktaran Yahya Kemal bu konuşmalarında sık sık şiirin ve edebiyatın dışına çıkar. Bu sohbetlerde Ömer Seyfettin, Abdülhak Hamit, Ahmet Haşim gibi yazarlar hakkında ileri geri konuşulur.

Okuyucu, başlı̆̆ın da yönlendirmesiyle metinde, Yahya Kemal'in şiirlerinden, şiirlerinin iç ve dış unsurlarından, bu şiirlerin öncesiyle-sonrasıyla Türk şiir tarihindeki yerinden hareketle oluşturulan/geliştirilen estetik ölçütü bir türlü bulamaz ve yazı, "ben ... eminim" şablonuna oturtulabilecek şu paragrafla biter:

"Ben Yahya Kemal’in, hem şiirleri hem de şiir hakkındaki yazılarıyla, Türk şiirinin sağlam bir ölçütü olduğundan ve gelecekte yeniden üzerinde durulacağından eminim.” ${ }^{15}$

\section{“Ölçü/t" ve “öncü” bahsinde bilimsel yol: Yargı kalıpları}

Edebiyat bilimiyle uğraşan araştırmacıların uzun soluklu çalışmalar sonucunda elde ettikleri veriler, bu verilerin tasnif edilip birbirine eklenmesiyle oluşan yeni bilgiler, bu yeni bilgilerin belli yöntem ve yaklaşımlarla kayıt altına alınması süreci, zamanla belli disiplin ve anlatım/bilgi/yargı kalıplarının

\footnotetext{
14 İnci Enginün, "Yahya Kemal: Edebiyatta Ölçüt”, Hayal Şiir Yahya Kemal Beyath Şüri Üzerine Makaleler, Türkiye İş Bankası Kültür Yayınları, İstanbul 2008, s. 154.

İnci Enginün, "Yahya Kemal: Edebiyatta Ölçüt", Hayal Şiïr Yahya Kemal Beyath Şüri Üzerine Makaleler, Türkiye İş Bankası Kültür Yayınları, İstanbul 2008, s. 164.
} 
ortaya çlkmasına zemin hazırlar. Bilginin aktarılması sürecinde oluşan bu anlatım kalıpları arkadan gelen araştırmacılar tarafından hem kullanılır hem geliştirilir.

$\cdots$

Ömer Faruk Akün, TDV İslâm Ansiklopedisi”ne yazdığı “Divan Edebiyatı” maddesinin hemen başında bir tanım yapar. Bu tanımda, divan edebiyatının yaklaşık olarak başlangıç ve bitiş zamanları, böyle bir edebiyatın ortaya çıkışına zemin hazırlayan teorik ve estetik faktörler/kaynaklar ile bu edebiyat geleneğinin ana karakteri metnin içine ustaca yerleştirilir:

"Türk edebiyatının umumi gelişimi içinde, nazarî ve estetik esaslarını İslâmî kültürden alarak meydana gelen ve özellikle örnek kabul ettiği Fars edebiyatının her yönden kuvvetli ve sürekli tesiri altında şekillenip belirgin örneklerini vermeye başladığı XIII. yüzyıl sonlarından, XIX. yüzyılın ikinci yarısına kadar, bünyesini sarsıcı ve zayıflatıcı bir tepki ve değişikliğe uğramadan Arapça-Farsça kelimelerin geniş ölçüde yer aldığı bir dille varlığını altı asır sürdürmüş bir edebiyat geleneğidir.”16

Akün'ün, divan edebiyatını tanımlarken kullandığı bu yöntem -biraz daha genişletilip- "Yeni (Modern) Türk Edebiyatı”nın tanımı için bir şablona dönüştürülebilir:

"Yeni (Modern) Türk Edebiyatı, Tanzimat Fermanı sonrası oluşan tarihi, siyasi ve kültürel hareketliliğin etkisiyle 1859-186o'l yıllarda İstanbul'da ve özellikle aydınların ikamet ettiği köșk, yalı ve konaklarda ortaya çııı günümüze kadar devam eden; roman, hikâye, tiyatro, makale gibi Batı kökenli türlerin Türk edebiyatında yavaş yavaş kendilerine yer bulmalarıyla ve bilhassa Batı'dan yapılan çevirilerle filizlenen; Sadullah Paşa, Akif Paşa, Ahmet Cevdet Paşa, Münif Paşa, İbrahim Şinasi gibi aydınların öncülügünde, divan geleneğinin karşısına halk edebiyatı ve kültürünün çıarılmasıyla oluşmaya başlamış ve bütün bunlarla birlikte temel ilhamını Batı'dan ve başlangıçta özellikle Fransız edebiyatçı ve filozoflarından almış bir edebiyat sürecidir.”17

Nüket Esen, Fatma Aliye ile ilgili bir yazısında, edebiyat araştırmacılarının çokça kullandıkları kalıp bir anlatımın somut örneğini verir. Önce tarihsel süreç olarak "ilk" olanı tespit eder, daha sonra türü benimsemesi ve türe katkısı bağlamında “öncü yazar”lığa vurgu yapar:

“illk kadın romancımız Fatma Aliye’nin yazar olma serüveninde çevresindeki erkeklerin rolü dikkat çekicidir."

Bu cümleden sonra şöyle bir dipnot vardır: “ 'Fatma Aliye'nin 1891'de yayınlanan ilk romanı Muhazarat'tan önce, 1877'de Zafer Hanım'in Aşk-ı Vatan (Zafer Hanım, Aşk-ı Vatan, yay. haz. Zehra Toska, İstanbul: Oğlak Yayınları 1994.) adlı romanı yayınlanmıştır. Fakat bu yazarın tek romanıdır. Oysa Fatma Aliye beş roman yazmış, çeşitli makale ve çevirileriyle zamanında ilk kadın romancı olarak tanınmıştır. İlk Türk romanı, Taaşşuk-ı Talat ve Fıtnat'ın yazarı Şemsettin Sami de başka roman yazmadığı için, ilk Türk romancısı olarak Ahmet Mithat anılır. Bunun gibi şu andaki bilgilerimizin ışığında roman yazan ilk Türk kadını Zafer Hanım'dır, ama Fatma Aliye'yi ilk Türk kadın romancısı olarak anmak gene de yerindedir."18

16 Ömer Faruk Akün, “Divan Edebiyatı”, TDV İslâm Ansiklopedisi, Cilt: 9, TDV Yayınları, İstanbul 1994, s. 389.

17 Muharrem Dayanç, "Yeni Türk Edebiyatının Kaynakları", Yeni Türk Edebiyatına Giriş, Anadolu Üniversitesi Yayınları, Eskișehir 2016, s. 39.

18 Nüket Esen, "Bir Osmanlı Kadın Yazarı Doğuşu: Fatma Aliye”, Modern Türk Edebiyatı Üzerine Okumalar, İletişim Yayınları, İstanbul 2006, s. 87. 
M. Fatih Andı’nın, yeni Türk şiirinde naat türünün değişimini anlatırken Mehmet Âkif in “Pek Hazîn Bir Mevlid Gecesi” adlı şiirinin içeriğiyle ilgili yaptığı tespit, Türk şiir tarihinin bir yönüne ayna tutması bakımından kıymetlidir:

“... Onun ‘Pek Hazîn Bir Mevlid Gecesi’ başlıklı şiiri, yeni Türk şiirinin na’tleri içerisinde çok farklı ve öncü bir mevkide durur. Osmanlı Devleti’nin büyük çalkantılar, savaşlar ve bozgunlarla geçen II. Meşrutiyet sonrası yıllarının, özellikle de Balkan Savaşları'nın doğurduğu halet-i ruhiyenin etkisiyle bir Mevlid gecesinde yazılmış olan bu şiir, Hazret-i Peygamber'e yönelişte O'nu hatırlayış ve O'na seslenişte bir dönüm noktasıdır. 1914 tarihli şiirde Âkif, kendisinden önceki şairlerden çok farklı bir biçimde ümmetin içinde bulunduğu sosyal ve siyasal şartlardan şikâyet eder ve Hazret-i Peygamber'e bir kurtarıcı olarak yönelip istimdâdda bulunur. Bu yaşanan reel durumdan şikâyetle kurtarıcı olarak Peygamber'e böylesi bir sesleniş, na’t edebiyatımızda yeni bir ses, yeni bir tavırdır. Zira artık Peygamber, günahkâr şairin ahiretteki şefaatçisi olmak yerine ruhaniyetiyle bu dünyadaki kötülüklere de müdahale etmeye, ümmet için kurtarıcı bir sahip olmaya davet edilmektedir."19

Nüket Esen ve M. Fatih Andı'nın yukarıda örnek olarak verilen tespitleri zamanla ortaya çıkacak yeni bilgiler ışı̆̆ında değişebilir, gelişebilir, güncellenebilir. Gelişip değişmek ve güncellenmek bilimin en temel kurallarından biridir.

Tanpınar'dan aktaracağımız bir bilgi şablonuyla konuyu biraz daha sarîh kılmak isteriz. 1951 yılında Varlk Dergisi’nde yayınlanan bir ankete verdiği cevapta Tanpınar önce ülkedeki kitabevlerinin pek de iç açıcı olmayan durumlarına vurgu yaptıktan sonra konuyu metnin birinci muhatabı Yaşar Nabi’ye getirir. Yaşar Nabi’nin şahsıyla birlikte kurduğu yayınevinin Cumhuriyet dönemindeki yerine değinen Tanpınar geçmişten verdiği örneklerle konuyu modern Türk edebiyatını anlamanın “ölçüt”üne dönüştürür:

“Şurası da var ki, kitapçılığımız çok zayıf. Kitabevlerimiz daha kârlı buldukları için mektep kitabı basmakla meşgul. Onun dışındakine devlet bile alâkadar değil. Nitekim başka şartlar altında daha ucuz olarak temin edilen kâğ bana öyle söylediler. Faydalı kitap... İyi ama, bunu kim tâyin edecek? Bir kitabın macerası o kadar değișebilir ki... Fakat asıl derdi unutmayalım. Hattâ bizde bile her edebî inkişaf kitapçıya bağlı olmuştur. Siz olmasaydınız (Yaşar Nabi), bugünkü yeni edebiyat teşekkül etmezdi. Ahmet İhsan olmasa Servet-i Fünûn muharrirleri, Ebuzziya olmasa Namık Kemal yarım kalırdı.”20

Yukarıdaki bilgileri kategorize edersek şöyle bir tablo ortaya çıkar: Ebuzziya olmasaydı Namık Kemal, Ahmet İhsan olmasaydı Servet-i Fünûn, Yaşar Nabi olmasaydı Cumhuriyet dönemindeki yeni edebiyat kendisine yaşama alanı bulamazdı.

Yukarıdaki “ölçüt”ü edebiyat tarihinin birçok alanına ve şahsına uyarlamak mümkündür. Mesela, Şinasi olmasaydı Namık Kemal, Namık Kemal olmasaydı Abdülhak Hamit ve Recaizade Mahmut Ekrem, Abdülhak Hamit ve Recaizade Mahmut Ekrem olmasaydı Servet-i Fünûn olmazdı... Bu neden sonuç ilişkisi bugüne kadar getirilebilir.

19 M. Fatih Andı, “Modern Türk Şairinin Hazret-i Peygamber İdrâki”, Şïrin Ufku Hz. Peygamberï Şürle Sevmek, Şule Yayınları, İstanbul 2017, s. 17.

20 Ahmet Hamdi Tanpınar, “Ahmet Hamdi Tanpınar Anlatıyor”, Yaşadığım Gibi, Dergâh Yayınları, İstanbul 200o, s. 310. 
Bu ölçü/mantık dönemlerinin yol açıcı bütün şahsiyetleri için de uygulanabilir. Bu bahisle ilgili olarak akla gelen şahsiyetler, Ahmet Mithat Efendi, ${ }^{21}$ Yahya Kemal, Ahmet Haşim, Necip Fazıl, Nazım Hikmet, Ömer Seyfettin, Memduh Şevket vb. şeklinde sıralanabilir.

\section{Ölçü oluşturmanın popüler yolu: Klişeler}

Geçmişle ilgili herhangi bir dönemi, akımı, topluluğu, süreci genelde çarpıcı bir cümle/mısra/aforizma veya kısa manzum bir ifadeyle özetleme durumu/alışkanlığı her gün biraz daha yaygınlaşmaktadır. Yorumu kişiden kişiye daralıp genişlemekle, değişip dönüşmekle birlikte bu tür kullanımlar ele aldıkları konuları zamanla görünür kılan/somutlayan/genelleyen birer "ölçüt” gibi de algılanmaya başlamıştır. Bunların ilk akla gelenleri şöyle sıralanabilir:

-“Ben tebaamdan Müslümanları camide, Hristiyanları kilisede, Yahudileri havrada görmek isterim.” (II. Mahmud'un 'Osmanlıcılık’ özetleyen sözü.)

-"Milletim nev-i beşerdir; vatanım rûy-i zemin". (Şinasi); "Toprak vatanım nev-i beşer milletim". (Tevfik Fikret) (Şinasi ve Tevfik Fikret'in, sınırların ortadan kaldırılarak dünyanın tek millete dönüşmesini temenni ettikleri/vurguladıkları, hümanizmi çağrıştıran, sözleri.)

-“Şinasi Mektebi”. (Tanzimat’’n birinci nesli ile Şinasi’nin öncülüğünü vurgulayan ifade.)

-“Zerrâttan şümûsa kadar her güzel şey şïrdir”. (Recaizade Mahmut Ekrem) (Tanzimat'ın ikinci neslinde şiirde konu bahsine yeni bir bakış.)

-“Yeni Edebiyat-ı Cedide”. (Menemenlizade Mehmet Tahir) (Servet-i Fünûn edebiyatının dönemin bir yazarı tarafindan farklı bir yaklaşımla ifade edilmesi.)

-“Ben bir Türk’üm dinim, cinsim uludur”. (Milli edebiyatı başlattı̆̆ı düşünülen Mehmet Emin’in misrası.)

-“Biz o şïri isteriz ki çifte giden analar

Ekin biçen genç kızlarla odun kesen analar

Yanık sesin dinlerlerken göz yaşların silsinler". (Mehmet Emin'in, dolayısıyla Milli edebiyat anlayışında olanların, yazılmasını istedikleri şiirin temel nitelikleri.)

-“Yalnız senin gezdiğin bahçede açmaz çiçek

Bizim diyarmız da binbir bahar saklar". (Faruk Nafiz) (Milli edebiyatın Anadolu ve Anadolu'nun değerlerini/gerçeklerini öne çıkarmasına yapılan poetik vurgu.)

-“Edebiyat şahsi ve muhteremdir”. (Fecr-i Âti’nin ana ilkesi.)

-“Ne harâbi ne harabatiyim

${ }_{21} \quad$ Sema Uğurcan, “Ahmet Mithat Efendi ve Elinden Tuttukları”, Merhaba Ey Muharrir -Ahmet Mithat Üzerine Eleştirel Yazılar-, Hazırlayanlar: Nüket Esen-Erol Köroğlu, Boğaziçi Üniversitesi Yayınları, İstanbul 2006, s. 289-308. 
Kökü mazide olan âtiyim”. (Y. Kemal), “... Millî hayat devamdır. Devam ederek değgişmek, değişerek devam etmektir”. (Tanpınar) (Yahya Kemal ve Tanpınar'ın kültürde devamlılığı (imtidadı) anlatan sözleri.)

-“Bizim romanımız şarkılarımızdı»”. (Y. Kemal) (Şarkılardaki bireyselliği öne çıkaran söz.)

-“Mektepten Memlekete”. (Y. Kemal) (Avrupa mektebinden memleket gerçeklerine/öze dönmeyi sembolize eden klişe ifade.)

-"Sözüm odun gibi olsun hakikat olsun tek”. (Mehmet Akif'in sanat/gerçeklik anlayışını özetleyen misrasi.)

-“Aruz sizin olsun hece bizimdir

Halkan söylediği Türkçe bizimdir

Leyl sizin, şeb sizin, gece bizimdir

Değildir bir mana üç ad’a muhtaç”. (Ziya Gökalp’in Milli edebiyatın ilkelerine gönderme yapan dörtlüğü.)

-“Canllhk, samimiyet ve daima yenilik”. (Yedi Meşaleciler’in ana ilkesi.)

-“Putları kırıyoruz”. (Nazım Hikmet’in geçmişe açtığı savaşta yazıya döktüğü görüşlerinin başlığı.)

-“Modern Türk edebiyatı bir medeniyet krizi ile başlar". (Tanpınar’ın bu cümlesinin, yeni/modern bir edebiyatın ortaya çıkışının başlangıcını/özünü veren en çarpıcı ifadelerden biri olduğu düşünülür.)

-“Rakı şişesinde balık olsam”, "Yazık oldu Süleyman Efendi’ye”. (Garip’le özdeşleşen, bu topluluğu akla getiren Orhan Veli’nin misraları.)

-“Lâleli’den dünyaya doğru giden bir tramvaydayız”. (Cemal Süreya’nın bu mısrası Sezai Karakoç’a göre İkinci Yeni’nin ana istikametini gösterir ve onun diğer hareketlerden ayrllan yönüne vurgu yapar.)

-"Mısra işlevini yitirdi”. (Edip Cansever); "Şïir geldi kelimeye dayandı", "Folklor şüire düşman”. (Cemal Süreya). (Edip Cansever ve Cemal Süreya'ya ait bu mısralar İkinci Yeni’yi sembolize eder.)

-“Tanpınar, Türkiye'dir”. (Besim Dellaloğlu) (Türkiye nedir, sorusunu akla getiren modern bir aforizma.)

\section{Sonuç veya ölçüt belirlemenin ölçüsü ne olmalı?}

Genelde sosyal bilimler, özelde edebiyat ve şiir bahsinde bilimsel bir ölçüt ortaya koymak, bu ölçütten hareketle çalışmalar yapmak hem çalışmaların seviyesini hem de bunların ulusal ve uluslararası değerini hatırı sayılır bir şekilde artıracaktır.

Fakat bu ölçütleri belirlemenin ölçüsü ne olacaktır? 
$\mathrm{Bu}$ temel sorunun cevabını bulmak, biraz da, edebiyat kuramlarını merkeze koyarak düşünce üretmekten geçer. Özellikle yirminci yüzyılın başından itibaren edebiyat kuramları sınır aşırı bir nitelik arzetmeye başlar. Mesela, Gustave Lanson İlimlerde Usul Edebiyat Tarihi adlı eserini 1909-1910'lu ylllarda kaleme almış, ortaya koyduğu ilkeler aradan çok zaman geçmeden başta Fuat Köprülü olmak üzere Türk edebiyat tarihçilerini etkilemeye başlamıştır.22 Daha sonra, R. Wellek-A.Warren'ın 1949'da Amerika'da birlikte yayınladıkları Edebiyat Biliminin Temelleri adlı eserle, öncesi olmakla birlikte, edebiyat araştırmacılarının dikkati dıştan (çevreden) içe (eserin kendisine) yönelmiştir. Bu eserle ortaya çlkan kuram (Yeni Eleştiri) Mehmet Kaplan başta olmak üzere edebiyat araştırmacıları üzerinde etkili olmuş, bu etki başka kuramlarla da beslenerek varlığını bugüne kadar devam ettirmiştir.

Ölçüt belirleme bahsinde başka dünyalara açılmanın önemini/gereğini tartışırken R. WellekA.Warren'ın, edebî eseri edebî olmayan eserden ayırırken ortaya koyduğu ana kavramları (veya başka bir ifadeyle ölçütleri) buraya almakta yarar var:

“... Edebî eserlerle edebî olmayan eserleri birbirinden ayıran farklar, unity in variety (çoklukta birlik), disinterested contemplation (tarafsız düşünme), aesthetic distance (estetik mesafe), framing (konunun sınırlandırılması), invention (sanatkârın eserinde yeni buluşlar sergilemesi), imagination (hayal gücü) ve invention (yaratıcılık) gibi eskiden beri kabul edilegelmiş estetik deyimlerin semantik bakımdan, yani başka kelimelerle tekrarlanmasından ibarettir."23

Yukarıdaki yedi kavram geliştirilebilir veya daraltılabilir fakat tamamen yok sayılamaz. Bu da oluşturulacak ölçütlerin bir tarafının, Fethi Naci'de de görüldüğü üzere, mutlaka evrensele açılması gerektiğini bize gösterir. Murat Belge, Garip ve İkinci Yeni şiir hareketlerini, sadece siyasal/yerel yaklaşımlarla değil, "uluslararası bağlamda" da tartışmak gerektiğine vurgu yapar. Belge’ye göre bu edebî hareketlere mensup sanatçllar, etkilendikleri kaynaklar ve yazdıkları şiirler bağlamında evrensele açılmışlardır:

\begin{abstract}
"Edebiyatı mümkün olduğu kadar geniş bir uluslararası bağlam içinde tartışmayı doğru ve gerekli buluyorum. Bizim eleştiri pratiğinde genellikle yapılmayan bir şey bu. Yapılmayınca, bu edebiyat adına 'Türkiye' denilen özel bir saksıda boy atmış bir bitkiye benzemeye başliyor. Oysa Türkiye'de üretilen edebiyat (şiir, roman vb.) bu tutumun gösterdiği gibi dünyadan kopuk değil. Burada ele aldığım şairlerden bazıları (birçoğu: Çelebi, Garip kuşağının üç şairi, İlhan Berk, Cemal Süreya, Ülkü Tamer, Can Yücel, yani yabancı dil bilenlerin hemen hepsi) şiir çevirisi de yapmış insanlar. Fransız şiir geleneğinin yoğun etkisi ellilere kadar sürmüş. Garip şiirini 'tek-parti rejiminin’ biçimlendirdiğini söyleyen var da, söz gelişi Jacques Prévert etkisini inceleyen yok. Benzer biçimde, İkinci Yeni’nin 'Menderes İktidarı' kadar 'Imagism' akımından etkilenmiş olabileceği pek tartışılmadı.”24
\end{abstract}

Toparlamak gerekirse, Türk edebiyatını/şiir birikimini -beslendikleri kaynakları gözardı etmedenkarşılaştırmalı/evrensel yaklaşımlardan da yararlanarak oluşturulacak estetik ölçütlere göre değerlendirmek artık elzemdir. Nitelikli araştırmacı/eleştirmen ölçüte giden yolda önüne çıkacak başta dil ve kültür farkı olmak üzere bütün engelleri aşmak zorundadır. Yine bu tür ölçütlerin, bu yazıdaki örneklerde öne çlkan "ben”, "bence", "bittecrübe/öyle sanıyorum" gibi temellendirmekten uzak yargilara yaslanmaması gerekir.

\footnotetext{
${ }_{22}$ Gustave Lanson, İlimlerde Usul Edebiyat Tarihi, Çev. Yusuf Şerif, Remzi Kitabevi, İstanbul 1937, 48 s.

${ }_{23} \quad$ R. Wellek-A. Warren, "Edebiyatın Mahiyeti”, Edebiyat Biliminin Temelleri, Çev. Ahmet Edip Uysal, Kültür ve Turizm Bakanlı̆̆ı Yayınları, Ankara 1983, s. 30.

24 Murat Belge, “Önsöz”, Şairaneden Şiirsele Türkiye'de Modern Şïr, İletișim Yayınları, İstanbul 2018, s. 15
} 
Ayrıca, "bilimsel yargı kalıpları" ve "edebiyat klişeleri” ölçünün özünü zedelemedikleri, anlama ve kavrama giden yolu kısalttıkları sürece faydalıdırlar denilebilir.

Son söz olarak, Türk edebiyatında ortaya çıan ölçütlerin önemli bir bölümünün değer yargılarından çok beğeni yargılarına yakın durduğunu, bunun nedeninin ise teorik alt yapı eksikliği ile kuramların edebiyat araştırmalarındaki öneminin anlaşılmaması olduğu söylenebilir.

\section{Kaynakça}

Akün, Ö. F. (1994). Divan Edebiyatı. Diyanet Vakfi İslâm Ansiklopedisi (s. 389). İstanbul: Türkiye Diyanet Vakfi.

Andı, M., F. (2017). Şïirin Ufku Hz. Peygamberi Şïrle Sevmek. İstanbul: Şule.

Belge, M. (2018). Şairaneden Şiirsele Türkiye'de Modern Şïr, İstanbul: İletişim.

Cansever, E. (2012). Şïri Şïrle Ölçmek, Şïri Şürle Ölçmek Şür Üzerine Yazılar, Söyleşiler, Soruşturmalar, (D. Dirlikyapan, Yay. haz.) İstanbul: YKY.

Dayanç, M. (2016). Yeni Türk Edebiyatının Kaynakları, Yeni Türk Edebiyatına Giriş, Anadolu Üniversitesi Yayınları, s. 39.

Enginün, İ (2008). Hayal Şür Yahya Kemal Beyath Şiïri Üzerine Makaleler. İstanbul:Türkiye İş Bankası Kültür.

Esen, N. (2006). Modern Türk Edebiyatı Üzerine Okumalar. İstanbul: İletişim.

Lanson, G. (1937) İlimlerde Usul Edebiyat Tarihi (Y. Şerif, Çev.) İstanbul: Remzi.

Moran, B. (1994). Edebiyat Kuramları ve Eleștiri. İstanbul: Cem.

Naci, F. (1986). Türk Romanında Ölçüt Sorunu Eleştiri Günlüğü I (1980-1986). İstanbul: YKY.

Naci, F. (2002 ). Gücünü Yitiren Edebiyat-Eleștiri Günlüğü II (1986-1990). İstanbul: YKY.

Sarraute, N. (1985 ). Kuşku Çağı. (B.Kösemihal, Çev. ) İstanbul: Adam.

Şengül, A. (2006). Değişimin Öncüleri: Model Şahıslar ve Türk Edebiyatına Yansımaları Erdem Dergisi, 47, 129-154.

Tanpınar, A. H. (2000). Edebiyat Üzerine Makaleler. İstanbul: Dergah.

Tanpınar, A., H. (2000). Yaşadığım Gibi. İstanbul:Dergâh.

Taşçıŏ̆lu, Y. (2008). Modern Türk Şiirinin Oluşumunda Yahya Kemal'in Yeri, İstanbul Yahya Kemal Enstitüsü Mecmuası V, İstanbul: İstanbul Yahya Kemal Enstitüsü Neşriyatı, 749-753.

Tunç, M., Ş. (1938, 9 Ekim). Tanrı Şair. Cumhuriyet, s.--

Uğurcan, S. (2006). Merhaba Ey Muharrir -Ahmet Mithat Üzerine Eleştirel Yazllar, (N.Esen-E. Köroğlu, Yay. haz.) İstanbul: Boğaziçi Üniversitesi.

Uslucan, F. (2002, Mayıs-Haziran-Temmuz) Öncü Roman Kavramı Açısından Bereketli Topraklar Üzerinde, Hece -Türk Romanı Özel Sayısı 65-66-67, 622-641.

Ünlü, M. (1997). Türkçede Yazınsal Eleştiri. İstanbul: İnkılap.

Wellek, R. ve Warren, A. (1983). Edebiyat Biliminin Temelleri (A. E. Uysal Çev.) Ankara: Kültür ve Turizm Bakanlığı.

Zariç, M. (2014, Ekim). Abdullah Şinasi Hisar’ın Öncü Kişiliği, Sanatı ve Eseri Üzerine Notlar, Hece, 214 139-146. 